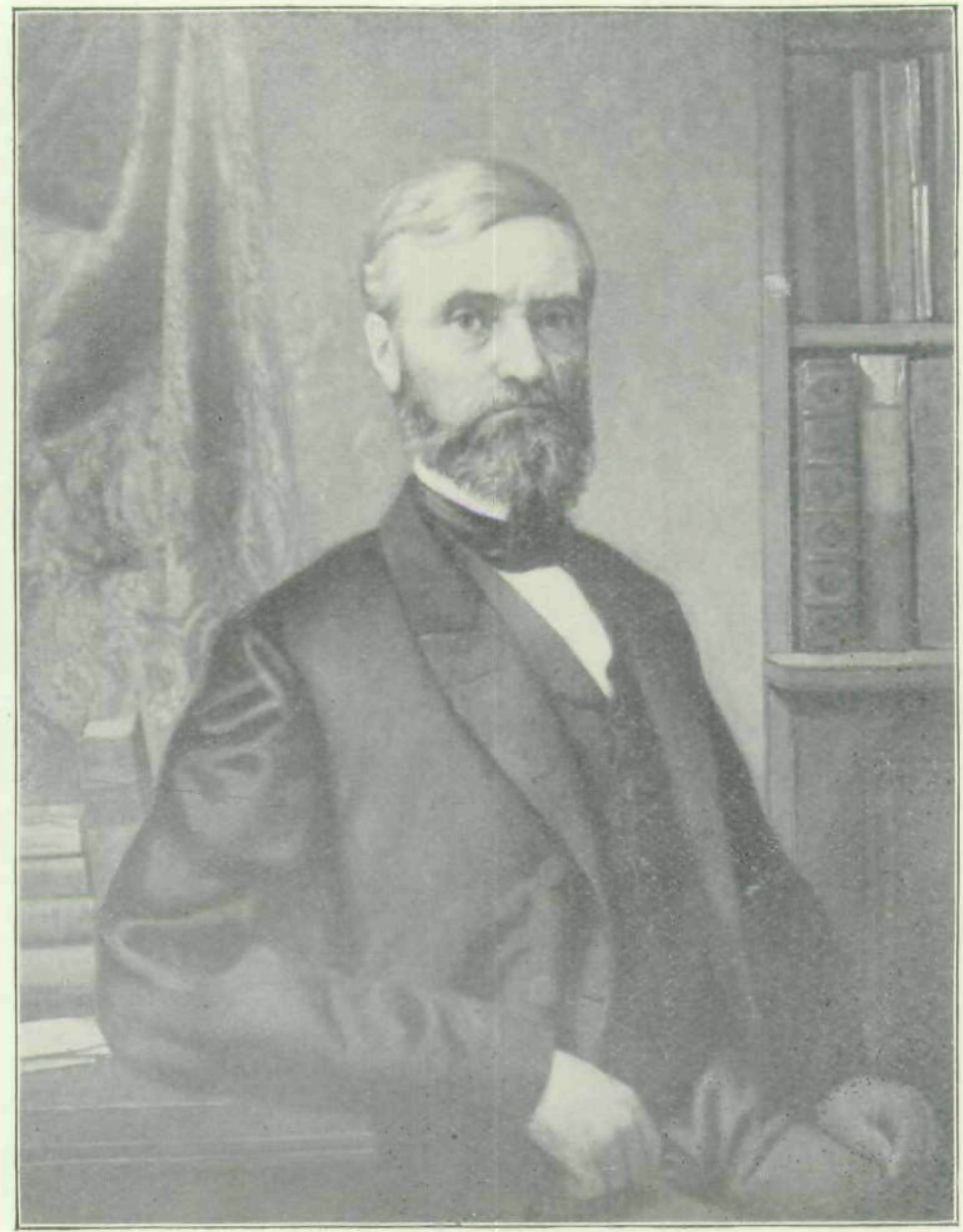

HON. CHARLES MASON,

First Chief Justice of Iowa Territory. 


\section{THE YEWELL PORTRAIT OF CHARLES MASON.}

Mrs. Mary J. Remey, wife of Captain Geo. C. Remey, of the United States Navy, in May last, sent to the Historical Department of Iowa, a fine oil portrait, from the easel of G. H. Yewell, N. A., of her illustrious father, the late Honorable Charles Mason, with the request that it be presented in her name by Ex-Chief Justice George G. Wright, to the Supreme Court of this State, for permanent keeping in its chambers. The 22d day of May, at 2 p. m., was indicated by Chief Justice Josiah Given as the time for the reception of the portrait. A large audience had assembled, when, npon the formal opening of the court, Judge Wright spoke as follows:

May it Please the Court: November 26th, 1838 May 22d, 1895 - almost fifty-seven years. On the first date Charles Mason, chief justice, with his associates, Joseph Williams and Thomas S. Wilson, commenced the first term of this court at Burlington. The only business transacted was an order for a writ of error to Muscatine county, and the first case decided, and one of world-wide importance, was in 1839, being Montgomery $v$ s. Ralph (a person of color) in which, the chief justice preparing the opinion, it was held that a slave under the laws of another state, brought by his master to Iowa, while under the protection of our laws must be permitted to go free. The Territory then had a population of about 25,000 , with, say, a dozen organized counties, and I doubt if a court-house in any. Now, ninety-nine organized counties, a population of at least $2,000,000$, and more business transacted in this court every term than in all the eight years of our territorial life.

And yet, no true friend of the state or its jurisprudence will despise the day of small things, or those figuring therein. For to do no more, think of the new chief justice, among the youngest ever called to a place so high, dignified and important, in this or any other Territory or 
state, and look at his surroundings and the difficult nature of the work before him. Without libraries, without a court-room worthy the name, without home precedents, with few if any around him with greater experience, a stranger to our laws and institutions, such as we had; a new people gathered from all parts of this and the old world, all untried in policies and inexperienced in legislation or judicial action-foundations to be laid, strong, or weak and perishable; called to so steer the judicial ship as to insure the best interests of the new land; and contemplate the advancement and progress which followed; the prudence, integrity and ability of himself and associates; and then our state, among the happiest, best and most prosperous in the strong and growing forty-four. How well their work was done I need not stop to inquire; content as I am to say that in no other Territory, if in any state, either from 1838 to 1846 , or before or since, was there safer judicial action, more unquestioned integrity among the incumbents, or apparently a higher or better appreciation of the great and momentous work imposed. And in this connection, but glance at the opinions announced for the eight years and you will see how great the proportion prepared by the young chief justice, and few, if any, of them after the lapse of fifty years, have been reversed.

Once more time passes and on the 25th of February, 1882 -more than thirty years since-this same chief justice "stepped from the topmost round of the ladder of earth to his home in the skies," and to-day, by the generosity and love of his devoted daughter and her worthy husbandthe latter among the most honored of our able naval officers - we welcome to this beautiful capitol, and, if possible, this more beautiful room, his portrait, which is to remain for all time a speaking and impressive reminder of one who labored so faithfully in laying the foundations upon which it is for you, as it has been for your predeces- 
sors, and will be for your successors, to so build as to bring no reproach to that bench which he honored, that profession which he loved, or the people whose highest interests he always sought to promote.

But what of his life? Briefly: Descended from Major John Mason, who distinguished himself in the famous Pequot (1637) war-he was born in Onondaga county, New York, October 24, 1804,-in 1825 entered the West Point Military Academy, where he graduated in 1829, first in his class, spending two years there as an instructorthen entered upon the study of law-in 1832 removing to Newburg in the state of his birth-thence to New York City in 1834; while there a frequent and valued contributor to its leading paper and for a time its sole editor-first visited the West in 1836 - was married in 1837 at Galena, Illinois, to Miss Angelica Gear (who died in 1873) — settled at once in Burlington-in 1838 was made chief justice, holding that position until the State was admitted into the Union in 1847 -after that by appointment of Governor Hempstead, the attorney for our state in the settlement, by the Supreme Court of the United States, of our Southern boundary - then a commissioner to prepare (with Hempstead and Woodward) the code of 1851-in 1853 made commissioner of patents which place he held until 1857 - then a member of our State board of education, provided for under the new constitution, and judge of Des Moines county - dying February 25, 1882, at his home in Burlington, near and in which place he had so long resided. Though from 1857 he was out of public life he was by no means inactive, but on the contrary prominent as a writer and author upon topics scientific and otherwise, connected with every movement looking to the advancement of his city - a leader in State and Nation in the strug. gles of the party of his choice for success, and retained in much important litigation, not in Iowa alone, but in other States, east as well as west, so that almost to the time of his 
death he was a busy man, his latter years if not so prominent as an official, none the less useful and helpful, nor the less admired by his family and friends.

Thus you will see in brief how active his life, what a prominent part this young man-settling in this new land before it had a separate existence-bore in shaping its policies and giving us our proud name. For a little more than forty years, when health permitted, he was a marked figure every day in some line, judicial, political, literary, scientific or business, and faithful to every trust, high or low, with a heart as tender as it was big, and a mind incisive, aggressive and ever on the side of truth and justice. Few if any men in Iowa made a more lasting impression in so many ways, by so many avenues, upon our early history; and few will be longer remembered by those who knew him or who will in after years consult our records, judicial or otherwise. I knew him well from April, 1841, when I was admitted to practice at a term then being held by him at Fairfield. If asked to state some of his characteristics I would say first, that he was a simple-hearted, honest and just man. He never toyed with wrong or bad habits. With an inflexible will he marched courageously to his conclusions, utterly indifferent to so-called technicalities, or as to who might be pleased or offended. Passionately fond of investigating every avenue of science, religion, and the whole field of advanced thought, and what he esteemed for the well being of his fellows, his mind was nevertheless a judicial one. He was a reticent man, not given to much talking, with a mind as pure as an infant's, and I doubt if he ever indulged in an impure thought. As I have stated elsewhere, he was a little awkward, and yet, owing undoubtedly to his military education, always manly and dignified in manner. Of his aggressive nature you will find abundant evidence in the report of the commissioners accompanying the code of 1851 . In these you have absolute 
demonstration that he was never a laggard, but ready to innovate upon established laws, and to strike into new paths however much he might be resisted by others. You will find, to say no more, that accepting the, to him, one great thought that women possess the same inherent rights that men do, he, on his own responsibility, recommended the most comprehensive legislation touching the rights of the wife to separate property, and the protection of that right, recommendations which even at this day after a lapse of more than forty years would strike the moss-covered legislator with alarm and be accepted with hesitation by even some of the most advanced thinkers on this subject. I know, too, that he was prepared for suffrage for women on the same terms as for man; that side by side with David D. Field he took the most radical ground in favor of codification in all branches of the law, and in many ways advocated reforms which would even now be regarded as unwarranted innovations. It may well be doubted if he had an equal in his disposition to investigate and develop new thoughts upon every subject, political, judicial, scientific and social.

I only add in this connection, that unerring in his judicial instincts, he was apt, as already intimated, to strike with the greatest directness to the marrow, the very heart of the matter before him. A friend to humanityof liberty in its broadest sense of right in all its strength and beauty - of justice in its most exalted form - he was hence so equipped that in his hands the law was gradually unfolded in its perfect symmetry and so magnified as to command the respect of all classes and conditions of men.

And finally, before I perform the formal but pleasant duty of delivering this conspicuously perfect work into your hands, I remark that though the great body of those around the chief justice and associated with him in developing this new land (for the new territory was not a creation but a growth), men, as already suggested, alike inex- 
perienced, and though they differed from him as from each other as to methods in legislation and otherwise, they were nevertheless grand and noble men, whose lives I shall never cease to admire, their memories to revere. For to say no more, I admire them because I look over our constitutions and statutes and there find the impress of their minds - I turn the leaves of journals, the tomes innumerable found in the inferior, intermediate and appellate courts of the State - examine our vast alcoves and receptacles, containing public records, and there see the results of their labors, the evidences of their industry. I look around and see our common schools, our higher institutions of learning, our churches, public buildings of every description, and find in them noble monuments of their liberality, their public spirit, their aid in the educational, religious and moral upbuilding of the State-I inquire for the master spirits who pioneered us through the early days and struggles of a frontier life and find these men, the compeers of the first presiding officer of this court, with him ever in the van, ready to do and doing their whole duty. I think also of the more than 80,000 men loyal to their State, who defiled from our hearthstones in defense of their country and their bright record in military annals, and rejoice that Hugh T. Reid, Samuel R. Curtis, M. M. Crocker, Samuel A. Rice, and scores of others whose names I cannot take time to mention, who, while honoring their profession, were the synonyms of all that was true, patriotic, brave, devoted, honorabie and deserving. And I look to the proud position Iowa occupies to-day in the sisterhood of States, our freedom from debt, the wisdom of our laws, the high character of our judicial and other officials, our advancement and progress, our love for and devotion to the Union, and rejoice that while not disparaging others, I can justly attribute much of all this to the untiring energy, active co-operation and public zeal of the early bar, (and among them, not by any means the 
least, the two grand men, W. H. Seevers and James F. Wilson, whose lives I am glad to know are to be suitably commemorated in your presence this afternoon,) largely influenced, if not led by the noble man whose portrait is soon to be placed in your keeping. So, as I repeat these things, because of such a record, I do honor the memories of these men, love to think of the "old guard," and recognize most gladly their helpful influence in giving us a State so prosperous, influential and truly great.

For the portrait about to be unveiled we are largely indebted to the active efforts of $\mathrm{Mr}$. Charles Aldrich, whose years of labor in the work committed to his hands are only equalled by his love for the State and the success of his department.

It comes to us from the hands of his daughter, a native of Iowa, as devoted to its good name as was her father. Then, as we shall look at the face and think of the artist from whose studio it comes we shall be led to say, that often "truth is stranger than tiction." A poor and friendless boy in Iowa City, more than half a century since, exhibiting. however, in his humble way undoubted genius as an artist, attracted the attention of Judge Mason, and being unable to obtain an education without aid, this good man (ever the friend of the poor and worthy) voluntarily and generously sent this boy, George H. Yewell, to New York City, then to France, Italy and Germany, paying all his expenses, and in time I need not say, for his fame is national and world-wide, he fully justified the judgment of his patron, and now in the maturity of his years and the ripeness of his genius gives to the daughter and State a work which, as you will see, almost speaks for the original, and as I believe, as some one else has said, embodies not the brains alone but the loving heart of this ever-grateful boy, who, in the fullness of his fame, owes so much to his noble patron and friend. 
Here, at the touch of Captain I. W. Griffith of Des Moines, the Ameriean flag, with which the portrait was draped, fell to the floor. Captain Griffith was a soldier in the Mexican war, losing his right arm at the battle of Churubuseo. He also served as bailiff in Judge Mason's court. Judge Wright concluded his remarks as follows:

And now deputed thereto by Mrs. Mary J. Remey, the daughter, and the husband, George C. Remey, I deliver this admirable portrait into your care, as the property of the people of this State. These children regret exceedingly their inability to be present-she writing: "The presentation of his (my father's) portrait to the State of Iowa, has long been a cherished wish of mine. * * * It will give me great pleasure to know that my tribute to his revered memory has been given to and accepted by the State to which he was so greatly attached. * * * Nothing would give us greater pleasure than to be present." In their behalf let me ask you to keep it sacredly as you value his memory, as you honor that profession and tribunal which he so honored, and thus in some small degree assist in preserving for future generations and keeping constantly before them the name and fame of one who took so large a share in giving us a State and institutions of which we are all so justly proud.

General George W. Jones, of Dubuque, spoke briefly but eloquently of Judge Mason's early life in Iowa Territory, of his appointment as Chief Justice, of his high eulture and many noble qualities, but his remarks were not reduced to writing or reported, and we are therefore unable to present them here.

In accepting the portrait on behalf of the State and the supreme Court, Justice L. G. Kinne said:

Gentlemen of the Bar of Iowa: The occasion of the unveiling and presentation to the State, through this Court, of a portrait of the first chief justice is one of historic importance. As the gift of the daughter of the late Chief Justice Mason, it is a fitting and tender tribute to one whose mature years were largely spent in its service, and whose history has become the proud legacy of this commonwealth and its people. Additional interest surrounds 
4. Thasles chason, do Labenwly suear that a will duffuont the bou stiution of the United Ltates, and nele and fuithpully execute the trast com= snitiea to ine, as tehief olustice of the dufireme leacut of the Lessitory F. Iava.

Turom st tabiciebea.

harlet Mavor

legene wue thes 2y'x

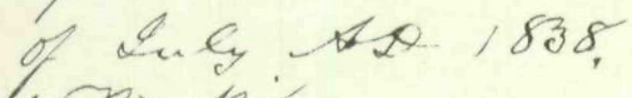

Pim 13 tan way

res of the derviting

of Sama.

Fac simile of Judge Mason's oath of office. The original is in possession of the Historical Department of Iowa. 
these ceremonies when we remember that the artist in painting this portrait was performing a labor of love to one who had befriended him, and made his future success and fame possible by tendering him substantial aid and encouragement at the beginning of his professional career.

As we look upon the portrayal of the features of Judge Mason, as we contemplate his work and worth, as we remember his services as a jurist and in other capacities, for the Territory and State of his adoption, we shall more fully appreciate them, and be the better able to give a just judgment as to their effect upon our State and its jurisprudence.

It is not my purpose to speak of Chief Justice Mason's private life, of his social qualities, of his family relations; these have been fully considered by those who enjoyed a personal acquaintance with him. It is of his public and official character that I shall briefly speak.

Before, however, proceeding to discharge this duty it is due to Judge Mason that his position during the war of the rebellion should forever and authoritatively be set at rest. His loyalty during that trying period was once publicly questioned, but without cause, and thus has a great injustice been done to this exemplary official and loyal citizen.

In November, 1886, there appeared, from a correspondent, in the Saturday Evening Post, of Burlington, a reference to Judge Mason, in which it was said that but for his love of Jefferson Davis he would have entered the Union army. This article, coming to the notice of ExSenator Harlan, he addressed a letter to the editor, the original of which is now before me, and which may be seen in the Iowa Historical Department, wherein he says: "Soon after the commencement of the war of the rebellion Judge Mason tendered his services to the Secretary of War, in any position in which it might be thought he could be useful. I personally know that this tender was 
made. The Judge's letter making it was addressed to me at Washington, and no doubt the letter itself is on the files of the War Department. * * * It impressed me at the time as singularly modest, coming from a man of his recognized eminence, and as patriotic as modest."

Senator Harlan's letter is lengthy and closes with a request that proper correction be made. In a letter of date December 19, 1894, Senator Harlan says he is not sure that this letter was published, and that "it is due the family that the facts should be known to the public." There can, in view of Senator Harlan's testimony, be no doubt that Judge Mason was a thoroughly loyal citizen of the republic.

Chief Justice Mason was an excellent example of judicial honor and integrity. Those who knew him personally unite in attesting that his was an honest life in every detail and respect.

Of him it may well be said:

"To his life has flowed

From its mysterious urn a sacred stream,

In whose calm depth the beautiful and pure

Alone are mirrored."

When the Territory of Iowa was organized Judge Mason was appointed Chief Justice of the Supreme Court, and served from 1838 until after the formation of the State government in 1847 , resigning in June of - the latter year. During these eight years or over the business of the court was small. Two hundred and twenty-eight cases only came bafore it, of these 221 are found reported in Morris, four in 1st Greene, and three in the Territorial report which are not to be found in Morris. It will be observed that the number of opinions written in over eight years was but a trifle in excess of those now written for a single term of this court. So rapid has been the growth in population, so multiplied and diversified the industries and necessities of our people, that litigation in a half century has so increased that during the present year this court will dispose of more than 550 cases. 
Nevertheless, in the years of the service of Chief Justice Mason on the bench the foundations of jurisprudence in Iowa were laid. Questions of great importance were heard and determined, precedents were established which have been followed ever since. The work then of the court was exceedingly important in that it gave form and direction to all future adjudication. It was indeed fortunate at this juncture, that the Territory of Iowa had the benefit of a man at the head of its highest judicial tribunal possessing the legal learning, the literary accomplishments, and the broad general culture of Chief Justice Mason.

A slight idea of the character of the litigation before the court in these years, may be better appreciated if we refer briefly to some of the cases.

Judge Mason's love of liberty is shown in the first case which came before the court, which involved the liberty of one Ralph, a colored man, where it was held that if a slave with his master's consent became a resident of a free State he could not be regarded thereafter as a fugitive slave, nor could the master, under such circumstances exercise any rights of ownership over him. In that opinion the learned Chief Justice said: "But, when he (the master) applies to our tribunals for the purpose of controlling, as property, that which our laws have declared shall not be property, it is incumbent on them to refuse their co-operation. When, in seeking to accomplish his object, he illegally restrains a human being of his liberty, it is proper that the laws, which should extend equal protec tion to men of all colors and conditions, should exert their remedial interposition."

In Gordon \& Washburn vs. Higley, Morris 19, it was held that a trial court might put in form a verdict of a jury - a doctrine ever since followed.

In Powell vs. U. S., Morris 24, it was held that an arraignment of the defendant, in a criminal case, was necessary. 
In Bell vs. Pierson, Morris 29, it was held that by appearance and pleading the defendant waived all defects in the process and in its service.

In Ballard vs. Ridgely \& Billon, Morris 37, it was held that when a rule or decision relating to the remedy has been changed by statute, the new rule is applicable only to cases subsequently tried.

In Maltby \& Bolls $v s$. Choper, Morris 80, the doctrine was first announced that the statute of limitations may be made to take effect on an antecedent contract.

When we consider the meager libraries of those days, the lack of precedents upon which to base legal judgments, we may to some extent appreciate the difficulties surrounding the judges and the profession in the proper discharge of their several duties, and we can the better understand the meed of praise due to such judicial pioneers as Chief Justice Mason, who, largely without legal guide or compass were compelled to adjudicate questions which were important and intricate, and upon a proper solution of which to a great degree depended the future rights of persons and property, in what was within a half century to become a commonwealth of over two millions of people. Surely, one might well shrink from the performance such a task. But the broad culture and legal learning of Chief Justice Mason were equal to the faithful and proper performance of every duty, judicial or otherwise. His official life was marked with a steadfast adherence to duty, a clear conception of the right, a profound knowledge of legal principles and the ability to apply the law with unerring accuracy to the facts.

Greater if possible than his labors on the bench was the value of the service he rendered the State after his retirement, as a member of the commission which formulated the Code of Iowa in 1851. In this work he was the leader, and it may be doubted if a better or a more concise code of laws had up to that time been compiled in any State. 
Time admonishes me that these remarks must close. This court, on behalf of the State he loved so well, and served with such signal fidelity and ability, accepts the portrait of its first Chief Justice. It shall adorn the walls of this temple of justice, and may the strong and kindly features portrayed in this picture be an incentive to us, and those who may follow us, to emulate his virtues, to adorn the bench as did he, and to leave to posterity a life without spot or blemish, so that at its close it may be said of us as we can now truthfully say of him:

"His life was gentle and the elements

So mixed in him, that Nature might stand up

And say to all the world-This was a man."

It is ordered that these proceedings be made of record.

To study history is to study literature.- The biography of a nation embraces all its works. No trifle is to be neglected. A mouldering medal is a letter of twenty centuries. Antiquities, which have been beautifully called history defaced, composed its fullest commentary. In these wrecks of many storms, which time washes to shore, the scholar looks patiently for treasures. The painting round a vase, the scribble on a wall, the wrath of a demogogue, the drollery of a farce, the point of an epigram, each possesses its own interest and value. A fossil court of law is dug out of an orator; and the Pompeii of Greece is discovered in the Comedies of Aristophanes. $R$. $A$. Willmott.

What is public history but a register of the successes and disappointments, the vices, the follies; and the quarrels, of those who engage in contention for power? Archdeacon Paley.

A true delineation of the smallest man is capable of interesting the greatest man.-Carlyle. 
Copyright of Annals of Iowa is the property of State of Iowa, by \& through the State Historical Society of Iowa and its content may not be copied or emailed to multiple sites or posted to a listserv without the copyright holder's express written permission. However, users may print, download, or email articles for individual use. 